\title{
Lights in the Darkness: Counsel, Deliberation, and Illumination in the Letters of Adam Marsh
}

\begin{abstract}
Adam Marsh (d. 1259) was a prominent spiritual counsellor to princes, prelates, and the superiors of his order. Counsel and exhortations are prominent features of his surviving letters, through which he sought to advance his theological vision, particularly with regard to the pastoral work of the church and its need for correction and reform. Although confident in the immutability of divine truth and its ultimate victory, Adam often expresses uncertainty and anxiety in his letters concerning what he and many of his correspondents viewed as a spiritually (and politically) fraught and dangerous landscape, in which truth had become more difficult to discern and sound counsel more difficult to provide. In his letters, Adam confronts the difficulties of such uncertainties and considers how he and his recipients can determine not only what is true but what course of action they ought to take. Over the course of various correspondences, Adam refers himself and others to several external sources of insight-the illumination of divine counsel, the exchange of human counsel, and the interchange of multilateral deliberation-all mechanisms which, to differing degrees, rely on the aid of both divine mercy and human fellowship in order to provide the support necessary to navigate the contingencies of changing circumstance. Together, these considerations emphasize the interconnectedness of those seeking the will of God, as those engaged in the active life rely on the prayers, exhortations, counsels, and even the disagreements of others to help them to navigate the darkness of temporal uncertainties.
\end{abstract}

\section{Introduction}

The Franciscan friar Adam Marsh (d. 1259) never held a high ecclesiastical office, but he rose to prominence during his lifetime as a spiritual counsellor and influential advisor to princes, prelates, and the superiors of his order. The letters which survive him are filled with counsels and exhortations through which he sought to advance his theological vision, particularly with regard to the pastoral work of the Church and its need for correction and reform. His contemporaries confirm the value they placed on such counsel: Robert Grosseteste, a former master of Adam's who shared much of his theological vision, wrote to him in the latter months of 1235 , shortly after being consecrated bishop of Lincoln, expressing his gratitude for Adam's effective persuasion. 'For I have learned from my experience of that persuasiveness,' he wrote, 'that you, and you alone, are a truthful friend, a loyal counsellor, a person whose concern is the truth and not what is illusory, and who rests on a firm and 
solid foundation, not on a hollow and fragile reed.' ${ }^{, 1}$ Despite their mutual dependence on this certain foundation of theological truth, however, Adam and Grosseteste still saw themselves as living in a time of great danger and uncertainty as the world drew inexorably closer to the Day of Judgement. Amidst what he and many of his correspondents viewed as a spiritually (and politically) fraught and dangerous landscape, even Adam was not immune to doubts and uncertainties, when truth had become more difficult to discern and sound counsel more difficult to provide. Indeed, uncertainty, as others have noted, proves a prominent feature of his letters. ${ }^{2}$

As a man frequently sought for his counsel, Adam was perpetually confronted with the difficulties of such uncertainties and forced to consider how they might be mitigated, not only for himself as an individual but within the network of friendships and connections evidenced by his letters. Even as he offered counsel and consolation to assuage the anxieties of others, he framed himself as a man who similarly required and was seeking insight and illumination: 'I am much disturbed by anxiety and uncertainty over the intricate question you have raised,' he writes in response to one such request for his counsel, 'because even before God I do not know how to give a clear answer. I have said this in no way as if I were offering counsel, but as one searching for what is true. ${ }^{3}$ Throughout his corpus of surviving letters, Adam returns repeatedly to these issues of truth and certainty, insight and discernment. How can he and those to whom he is providing counsel determine not only what is true but what course of action should best be followed? His letters' frequent imagery of light and darkness not only highlights the ongoing battle of good and evil, but also illustrates the difficulty of finding one's way with confident discernment without an external source of light. Over the course of various correspondences, Adam offers his considerations on several such external sources of insight, which can somewhat

1 Grosseteste, Epistolae, ed. Henry Richards Luard, Rolls Series (London: Longman, 1861), letter 20, p. 69; translation in Letters of Robert Grosseteste, Bishop of Lincoln, trans. Frank A.C. Mantello and Joseph Goering (Toronto: University of Toronto Press, 2010), pp. 101-2: 'In ipsa namque persuasione te solum expertus sum veracem amicum, fidelem consiliarium, respicientem veritatem non vanitatem, imminentem solido et firmo fulcimento, non vacuo et fragili baculo arundineo.'

2 Amanda Power, 'The Uncertainties of Reformers: Collective Anxieties and Strategic Discourses,' in Thirteenth Century England XVI: Proceedings of the Cambridge Conference, 2015, ed. Andrew M. Spencer and Carl Watkins (Woodbridge: Boydell, 2017), pp. 1-20. Power's essay focuses on the strategic and institutional implications of rhetorical uses of certainty by Adam and other 'reformers', rather than the theological means by which they mitigated their own anxieties and uncertainties.

3 Letter 75 to Richard Gravesend, Dean of Lincoln (28 May 1254), The Letters of Adam Marsh, ed. and trans. C.H. Lawrence, Oxford Medieval Texts, 2 vols (Oxford: Clarendon Press, 2006), vol. 1, pp. 190 - 91: 'Coarctationis pauide anceps anxietas meam admodum afflixit animam in hac uestre disertitudinis questione perplexa, cui quoniam ignoraui ecce coram Domino quid certius responderem, hoc locutus sum, nequaquam quasi prebens consilium, sed uelut uerum inuestigans (...).' (While this essay makes use of Lawrence's facing translation, it has often been silently amended for reasons of consistency and terminological exactitude. Few of the letters have sufficient internal evidence for precise dating; any suggested dates are Lawrence's.) See similar phrasing in Grosseteste, Epistolae, ep. XCIX to Walter Cantilupe (April 1242), p. 304. 
artificially be divided into three heavily intertwined categories: the illumination of divine counsel, the exchange of human counsel, and the interchange of multilateral deliberation. All of these mechanisms, to differing degrees, rely on the aid of both divine mercy and human fellowship in order to provide the support necessary to navigate the contingencies of the mutable sublunary sphere.

\section{Challenges of the Source Material}

Accessing Adam's theological thought through his writing presents some particular challenges when compared to some of his contemporaries: none of his theological works themselves are known to survive, leaving only a single manuscript collection of 245 of his letters, composed between 1241 and his death in $1259 .{ }^{4}$ This collection provides a limited and partial view of his many correspondences. Of the sixty letters we possess from Adam to Robert Grosseteste, for example, only two survive in the other direction. ${ }^{5}$ Further contextual difficulties arise from the fact that the letters, ranging from hasty notes to lengthy epistles, are largely undated, grouped by their Franciscan collectors according to their recipients without regard for chronological order. Adam's writing style, which looks to the masters of the dictamen for much of its orotund vocabulary and fulsome forms of address, is also not without its challenges, as scholars have been quick to note. ${ }^{6}$ Despite certain conventionalities and convolutions of form, however, Adam's spiritual convictions and desires still communicate themselves with force even to the modern reader, the more so as he frequently writes in a mode of fervent exhortation.

There are no indications that Adam ever intended these letters for collection or wider publication; even while drawing on dictaminal models, each letter is written for a particular recipient in particular circumstances. There is very little reliance on authorities other than scripture, and theological lines of thinking are often alluded to rather than developed. These are not methodical theological treatises; they are primarily pastoral letters of counsel, entreaty, and admonition, written by a man seeking to establish footholds of confidence and security in a world he considered to be entering ever more spiritual dangers. Adam's letters contain an application

\footnotetext{
4 British Library Cotton MS Vitellius C VIII, ff. 22r-84v. The lengthy final letter of the collection (letter 245), incomplete in the Cotton manuscript, is found in full in Oxford, Bodleian Library, Digby MS 104, ff. 90 - 101 and Vienna, ONB MS 4923 (Theol. 457), ff. 40v - 42v. On Adam Marsh's possible nonextant works, see Lawrence, 'Introduction,' in The Letters of Adam Marsh, vol. 1, pp. xvii-xviii. 5 Grosseteste, Epistolae, letters 9 and 20.

6 C.H. Lawrence, who edited and translated the collection, labelled it 'an elaborate and highly convoluted rhetorical style,' while John Maddicott has described the hallmarks of Adam's style as obliqueness, allusiveness, and the ability to cover pages without saying anything of much consequence: Lawrence, 'Introduction,' pp. xliv-xlvii; Maddicott, 'Review of The Letters of Adam Marsh: Vol. II,' English Historical Review 127:525 (2012), pp. 422-23.
} 
of his theological thought, conceptions, and ideas not just in the abstract, but marshalled and applied to particular situations and individuals. Even as he expressed his longings for the leisure of the contemplative life, Adam's connections to powerful people including at the royal court inevitably drew him into what he considered 'the disturbing business' (occupatio inquieta) of more political matters. ${ }^{7}$ Adam's persuasive intent shapes his use of language and imagery; he uses rhetoric of certainty and uncertainty, light and darkness, truth and deceit to strategic effect in advancing his own views about necessary reforms within the Church and society. ${ }^{8}$ Adam's views of divine illumination, counsel, and deliberation, rooted in longstanding theological discussions, are therefore applied in his letters with practical force as he seeks to 'accuse, plead, chasten and arouse people to the severe demands of salvation' and to give and receive guidance on how to discern truth and the right course of action. ${ }^{9}$

\section{Celestial Certainty and Temporal Anxiety}

Adam expresses no doubts as to the changeless certainty of divine truth and its ultimate victory. This immutability of divine truth undergirds his confidence in divine aid: 'Will the changeless truth of incomparable mercy refuse us what he bids us to ask when he has been asked for it?'10 The almighty God also provides the overall direction and destination for his path in life, being 'the way by which we travel, the truth at which we arrive, and the life in which we ever remain. ${ }^{\text {'11 }}$ The ultimate victory of the side of truth, in opposition to the evil forces of fraudulent seduction, should be self-evident; as Adam instructs Simon of Montfort, earl of Leicester: 'Only one whose mind is darkened by unbelief doubts ... that the truthful simplicity [simplicitas ueridica] of the faithful shall rebut the deceitful cunning [fallacem calliditatem] of the lost (...)'. ${ }^{12}$ At the same time, the Church still plays a critical role in the defence of this truth: a large part of Adam's deep concern for suitable leadership in the Church

7 Letter 73 to Walter Cantilupe, bishop of Worcester (1253), vol. 1, pp. 176-77. On Adam's political involvement, see Lawrence, 'Introduction,' pp. xxxvii-xliii and Amanda Power, 'The Friars in Secular and Ecclesiastical Governance, 1224-c. 1259,' in The English Province of the Franciscans (1224-c.1350), ed. Michael J.P. Robson (Leiden: Brill, 2017), pp. 28-45. Adam's role as a counsellor to the powerful was not without its setbacks: he writes of incurring Henry III's displeasure 'on account of [speaking] words of life [propter uerba vitae]' and subsequently being refused access to the king and queen for a time: letter 141 to Simon of Montfort (1250), pp. 348-49.

8 Power, 'The Uncertainties of Reformers,' pp. 7-8.

9 Letter 44 to Grosseteste, vol. 1, pp. 120-21.

10 Letter 245.9a to Sewal, archbishop of York (1256x1257), vol. 2, pp. 586-87.

11 Letter 47 to Grosseteste (7 March 1252), vol. 1, pp. 126-27; see John 14:6.

12 Letter 141 to Simon of Montfort (1250), vol. 2, pp. 342-43: 'Quis enim ambigit, preterquam is quem obtenebrauit perfidei caligo (...) quin fallacem calliditatem perditorum fidelium simplicitas ueridica refellat (...)'. 
stems from his belief that it is through the 'invincible leaders of the Church' that 'catholic truth is affirmed and heretical falsity refuted."13

The certainty of eternal truth and the confidence that it will eventually prevail cannot, however, entirely mitigate the shifting nature of decision-making on earth. This contingency does not undermine Adam's spiritual confidence, but he is very aware that it may require additional care in navigation. He writes that 'the wise man never fears the odious label of inconstancy where he clings with constancy to heavenly truth, which, according to the changing conditions of transitory things, though it remains constant, demands changes in one's counsels [precipit uicissitudines consiliorum]. ${ }^{14}$ The divine truth may remain constant, but one's consilium, one's plan or counsel, must adapt to changing circumstance. Humans living transitory lives must determine not only what is right and true, but also how to apply this to the decisions, plans, and actions which they are required to make in particular circumstances.

Adam repeatedly refers in his letters to his own anxiety amidst such uncertainty: to Grosseteste, for example, he writes of having a mind in suspense with long-standing doubts and uneasiness. ${ }^{15}$ Some of Adam's perplexity expressed in his letters concerns specific challenges, such as his uncertainty over how to give a clear answer to a request for counsel from Richard Gravesend, dean of Lincoln, regarding the collation of the prebend of Thame. ${ }^{16}$ Much of Adam's apprehension also relates more generally to the perilous state of the world which he believed to be drawing near to its end. He writes of:

very bad and dangerous times, when in almost the whole Christian world we see, for shame, those who have obtained the ministry of working for salvation turning (...) the highest office, shining truth [clarissimam ueritatem], and the fragrance of holiness into, alas, an arrogant display of power, a quest for ephemeral wealth, and the pleasures of lust. On this account, as though the abyss is opened and Satan unbound, a monstrous and omniform strength, unheard of for centuries past, opposes itself to the kingdom of God. ${ }^{17}$

13 Letter 245.24a, vol. 2, pp. 610-11.

14 Letter 172 to William of Nottingham, provincial minister of England (undated), vol. 2, pp. 414-15: 'Nunquam tamen formidat sapiens odibilem inconstantie notam, ubi superne ueritati constanter inheretur, que secundum rerum transmutabilium uarietates diuersas, taman eadem manens, precipit uicissitudines consiliorum.'

15 Letter 52 (3 June 1250), vol. 1, pp. 144-45: ‘(...) littera suspense menti nuper transmissa diutine prestolationis ancipitem sollicitudinem non mediocri subeleuauit exultatione.'

16 Letter 75 (see above, n. 3).

17 Letter 8 to James Erlandson, bishop of Roskilde (1251), vol. 1, pp. 18-19: ‘(...) presertim diebus pessimis periculosissimi temporis, cum conspiciantur, proh nefas, pene per uniuersum orbis Christiani spatium qui salutis operande celeste ministerium sunt assecuti, et altissimam dignitatem et clarissimam ueritatem et suauissimam sanctitatem in fastum pompatice potestatis, in questum euanide facultatis, in luxum sordide uoluptatis (...) detorquere. Propter quod contra regnum Dei usquequaquam seculis omnibus inaudita, quasi abysso rupta et soluto Satana, omniformis grassatur immanitas.' 
In the midst of a time Adam describes as characterized not only by violence but also by seductive and deceptive blandishments, when the leaders of the church 'flee without any courage before their pursuers,' he confesses to Grosseteste that 'for some days past, more than usually, I know not what should be done [quid fieri opus sit prorsus nescio] about these things which affect the profession of both your holiness and my wretched self,' expressing his longing for Grosseteste's guidance. ${ }^{18}$ Adam often frames such human ignorance in the context of divine omniscience. In a letter to some fellow Franciscan brothers, he writes that the remedy for the current evils is known only to God 'who sees the prayers of the humble.' Adam himself, contrary to his hopes, is in ignorance: 'For this reason,' he writes, 'I am in no way adequate to find what needs to be done,' his letters and speeches having failed to have had the desired result. ${ }^{19}$

Faced with such human deficiencies in knowledge, discernment, and efficacy, Adam must consider means of mitigation. Undergirded by a confidence in changeless divine truth and reaching from temporal uncertainties towards eternal certainties, he refers himself and his letters' recipients to the mechanisms of illumination, counsel, and deliberation in order to seek truth and determine what ought to be done in their particular circumstances. Adam prays throughout his letters for divine illumination from God, and in particular the spiritual gift of counsel, but also proffers his own counsel and solicits the counsel of others, while also advocating the value of multilateral discussion and deliberation, all as means of inquiring into the truth and determining what ought to be done.

\section{Divine Counsel and Illumination}

Throughout his letters, Adam refers to divine counsel as a necessity amidst uncertainties, and an essential source of truth and illumination. If humans lack the ability to see clearly, they must depend upon God for insight. 'In this abysmal darkness of the prince of the world,' he writes to Richard Gravesend, 'who will see what ought to be considered well-advised [consultum], except one who has been illuminated by revelations "coming down from the Father of heavenly lights" [James 1:17]?'20 Adam's choice of scripture here emphasizes the immutable certainty of such illumination; in the Father of lights, as the Vulgate continues, there is no change (transmutatio) or shadow of alteration (vicissitudinis obumbratio). Here we see the imagery of light and darkness which is pervasive throughout Adam's letters, particularly with regard to truth, knowledge, and discernment. Adam most frequently refers to such

18 Letter 38 to Grosseteste (undated), vol. 1, pp. 110 -11.

19 Letter 243, vol. 2, pp. 570 -71: 'Propter quod quid facto opus sit inuenire nullatenus sufficio (...).' 20 Letter 75, vol. 1, pp. 188-89: 'Sed inter has abyssales mundani principis obtenebrationes quid esset consultum censeri debeat, quis aliquatenus uidebit, nisi quem illustrant reuelationes "desursum descendentes a Patre luminum”?' 
divinely-bestowed insight as illuminatio, the giving of light - wording common in authorities such as the Vulgate, Augustine, and Pseudo-Dionysius. Such heavenly illumination pierces the blinding darkness of ignorance and moral contagion and provides new clarity of sight, allowing those who are illuminated to illuminate others in turn. ${ }^{21}$

Prayer allows petitioners to turn directly to the source of this divine light, and Adam naturally counsels those who face darkness and uncertainty to turn to the Lord, calling upon him to provide them with aid and illumination. In one letter, questioning what ought to be done regarding a certain urgent matter of business, Adam writes to Peter of Savoy that 'the infallible remedy for our fear of the outcome of uncertain events [ambiguorum eventuum exitus] is to follow the example of men who triumph and with untiring perseverance supplicate [the Lord] (...). Indeed, when we do not know what we ought to do [quid agere debeamus], let us cast all our care upon him who loves souls. ${ }^{22}$ Prayer concerns both the outcomes of uncontrollable events and the actions that one may decide to take in the face of them. Adam similarly writes to Eleanor of Montfort, regarding the difficulty of appointing a suitable priest to her household, that 'there can be only one counsel to offer in this matter, and that is to appeal humbly to him who judges not according to appearances, but sees into the heart. ${ }^{23}$ Such divinely-provided insight works in concert with other sources of authority and revelation. Adam speaks of 'high minds, illuminated to whatever extent by canonical tradition or the commands of the Gospel or heavenly inspirations or shining revelations,' who are able to attain an understanding of a more blessed and glorious justice. ${ }^{24}$ Adam repeatedly refers to inspiration as operating alongside Scripture, the examples of the saints, reason, and experience to direct the faithful and grant them clear sight of the truth. ${ }^{25}$

21 Letter 37 to Grosseteste, pp. 110 -11 (see below, note 51); letter 212 to Geoffrey of Brie, minister provincial of France (undated), pp. 518-19. Adam's letters are relatively unconcerned with the epistemological implications or mechanics of such illumination, generally focusing instead on illumination as an aid to practical discernment. On theories of divine illumination in the 13th century, see Lydia Schumacher, Divine Illumination: The History and Future of Augustine's Theory of Knowledge (Oxford: Wiley-Blackwell, 2011).

22 Letter 145 to Peter of Savoy (undated), vol. 2, pp. 360-61: 'Contra formidabiles ambiguorum euentuum exitus hoc infallibile semper recurrit remedium, quod secundum salutaria exempla uirorum triumphalium Illi diligentia indefessa supplicetur (...). Cum etenim ignoramus quid agere debeamus, omnem sollicitudinem nostrum in Ipsum proiciamus qui amat animas.' See also 2 Chronicles 20:12 and 1 Peter 5:7.

23 Matthew 3:9; letter 158 to Eleanor of Montfort, Countess of Leicester (1249x1250), vol. 2, pp. 382-83.

24 Letter 245.24a to Sewal, archbishop of York (1256x1257), vol. 2, pp. 610 -11: 'Qualiter unquam sublimes animi quantumcunque uel traditionibus canonicis uel euangelicis sanctionibus uel inspirationibus celicis uel lucidis reuelationibus illuminati, poterunt intelligere iustitiam aliquam beatioris glorie (...).'

25 See letter 245.28a, vol. 2, pp. 614-15 and letter 58 to an anonymous clerk, vol. 1, pp. 156-57. 
One particular means of illumination which Adam discusses is that of the gifts of the Holy Spirit, specifically the gift of counsel, frequently referenced in Adam's letters in conjunction with the gift of fortitude. The medieval conception of the gifts (dona) was derived from the seven 'spirits' listed in a passage of Messianic prophecy in Isaiah 11 - wisdom and understanding, counsel and fortitude, knowledge and piety, and the fear of the Lord. ${ }^{26}$ These gifts received an increasingly systematic treatment in the 12th and 13th centuries, although their precise nature and operation (such as their relation to the virtues) continued to be subject to debate. Texts which specifically addressed the gift of counsel generally focused less upon the bestowal of particular words of counsel from God and more upon its preparation of the heart to heed, and to desire to heed, the counsel of God and to imitate Christ, especially in matters of doubt or difficulty. ${ }^{27}$

Such discussions also frequently employed imagery of divine light or illumination providing clarity of sight. ${ }^{28}$ An influential early treatment was that of Gregory the Great, who in his Moralia in Iob stressed not only the distinct action of each gift, but also the gifts' interdependence. According to Gregory, the gift of counsel (consilium) stays us from acting precipitately and fills the mind with reason, while the gift of fortitude (fortitudo), fearing no adversity, gives the alarmed soul confidence. Each gift has its own weaknesses - counsel may multiply itself and grow into confusion, fortitude may give confidence in a way which leads into precipitate action - yet each also works against particular vices, counsel against rashness, and fortitude against fear. ${ }^{29}$ Each gift also depends on another: counsel is worthless without fortitude, since whatever it discovers through consideration it will never actually carry out in action; similarly, fortitude is destroyed without the support of counsel, since the greater it estimates its own power, the more it will rush headlong into

26 Isaiah 11:2-3.

27 For an overview of medieval theological treatments of the gifts, see D.O. Lottin, 'Les dons du Saint-Esprit chez les théologiens depuis P. Lombard jusqu'à S. Thomas d'Aquin,' Recherche de théologie ancienne et médiévale 1 (1929), pp. 41-97; Jacques of Blic, 'Pour l'histoire de la théologie des dons avant Saint Thomas,' Revue d'ascétique et de mystique 22 (1946), pp. 117-79. On the gift of counsel, see Carla Casagrande, 'Virtù della prudenza e dono del consiglio,' in Consilium: teorie e pratiche del consigliare nella cultura medievale, ed. Carla Casagrande, Chiara Crisciani and Silvana Vecchio (Florence: SISMEL, 2004), pp. 1-14. Systematic treatments of each of the gifts, largely missing from Lombard's Sentences, were added by his early commentators. On the gift of counsel, see Albert the Great, Super IV libros Sententiarum, III dist. 35 art. 5-8, in Alberti Magni Opera omnia, vol. 28, ed. Étienne César Auguste Borgnet (Paris: Apud Ludovicum Vivès, 1894), pp. 650-52; Bonaventure, In Sent., III dist. 34, q. 9, in Doctoris Seraphici S. Bonaventurae opera omnia, vol. 3 (Quaracchi: Collegium S. Bonaventurae, 1887), pp. 780 - 82; and Aquinas, Super IV libros Sententiarum, III dist. 35, q. 2, art. 4. 28 See, for example, Albert the Great, Commentarii III, dist. 35, art. 5-7, pp. 363-64; Bonaventure, Collationes de septem donis Spiritus sancti, in Opera omnia, vol. 5 (Quaracchi: Collegium S. Bonaventurae, 1891), VII.12, p. 491.

29 Gregory the Great, Moralia in Iob, ed. Marcus Adriaen, CCSL 143 (Turnhout: Brepols, 1979), I.xxxv.48, p. 51 and II.xlix.77, p. 106. 
ruin without the governance of reason..$^{30}$ The spirit of counsel, in Gregory's formulation, aids the act of deliberation, considering what ought to be done and making a reasoned choice, while the spirit of fortitude provides the strength with which to enact that choice.

It is unsurprising, therefore, that in the midst of uncertainties it is this pairing counsel and fortitude - to which Adam refers most frequently, most notably in his salutations and valedictions, in which he prays that the recipient of his letter will also be in receipt of these spiritual gifts. ${ }^{31}$ Adam is not unique in using this pairing in an epistolary context - while it does not appear in Grosseteste's contemporaneous collection of letters, it can be found, albeit infrequently, in earlier letter collections such as those of Ivo of Chartres and Bernard of Clairvaux. ${ }^{32}$ However, Adam's usage is striking both in its relative frequency and the context in which it appears. The dozen or so letters in which Adam references these gifts tend to concern matters of difficulty in which spiritual discernment and courage are evidently required. Adam actively prays in these letters for the divine gift of counsel and fortitude to be bestowed upon his letters' recipients so that they may be able to act rightly in their given circumstances.

Such prayers for divine aid by means of these gifts are much in evidence over the course of Adam's long friendship and correspondence with Robert Grosseteste. For example, Adam ends a letter about the lack of suitable pastoral candidates by writing that 'in the midst of such great and critical matters, I pray that Christ, the power of God and the wisdom of God, may grant you a spirit of counsel to plan your choice, and a spirit of fortitude to empower you to act. ${ }^{33}$ Here, the co-operation of this pair of gifts is evident. While the spirit of counsel aids the industria of decision-making, the spirit of fortitude provides the potestas necessary to carry that decision through to action. In another letter, Adam similarly prays on Grosseteste's behalf 'that in spiritual matters the spirit of counsel may go before you and the spirit of fortitude may

\footnotetext{
30 Gregory the Great, Moralia in Iob, I.xxxii.44, pp. 48-49.

31 See salutations of letters 58, 79, 90, 96, 97, 116, 123, 134, and 196, and valedictions of letters 20, 40, 72 , and 75 .

32 Ivo of Chartres, Epistolae (PL 162:11-288), letters 14, 196, 223, 247, and 270; Bernard of Clairvaux, Epistulae, in Bernardi opera, vol. 7-8, ed. J. Leclercq and H.M. Rochais (Rome: Editiones Cistercienses, 1974-77), letters 109, 134, 332, and 353. While the pairing of counsel and fortitude is not found in the salutations or valedictions of Grosseteste's surviving letters, he does consider the gift of counsel in Epistolae, letter 106 to Master Martin, p. 315, discussing it in the light of Aristotle's discussion of counsel in the Nicomachean Ethics, and letter 124 to Henry III, p. 350, treating it amongst the other spiritual gifts bestowed upon the king of England through the sacrament of anointing.

33 Letter 40 to Robert Grosseteste (undated), vol. 1, pp. 114-15: 'Det uobis, oro, inter tantarum rerum discrimina Christus, Dei uirtus et Dei sapientia, spiritum consilii ad electionis industriam, spiritumque fortitudinis ad executionis potestatem.'
} 
follow close behind,' again emphasizing the paired benefits of foresight and of enaction. $^{34}$

The spiritual gifts also provide aid when even friends are prevented from providing assistance themselves. Explaining that he will not be able to come to Grosseteste any sooner than previously arranged, Adam writes, 'It is not, in the light of frequent experience, to be expected that the spirit of counsel and fortitude, "with patience and the consolation of the Scriptures," will fail you in the cause of salvation,' even in the absence of such human counsellors as bishop Walter Cantilupe and himself. ${ }^{35}$ Indeed, the absence of human aid and counsel might even be providential, as a means of increasing one's dependence upon divine aid and counsel: having already referred Peter of Savoy to prayer, Adam notes that 'surely it is a dispensation of heavenly wisdom that sometimes removes human aid from desperately difficult causes,' causes which divine patronage will always magnificently bring to their fulfilment. ${ }^{36}$ Such trust in divine assistance is in keeping with the confidence Adam elsewhere expresses for those whom he sees as working faithfully for the Lord's cause. ${ }^{37}$

At other times, however, Adam's desire to see a spirit of counsel and fortitude in his recipient reads more as a reprimand. In one letter, Adam wishes an anonymous clerk 'a spirit of salutary counsel and a spirit of true fortitude [cum spiritu salutaris consilii spiritum valide fortitudinis]' and directs him to scripture, telling him, 'I fail to see how you can find a pretext to avoid without damnation obeying the call of Christ in the cause of salvation transmitted to you through a religious superior. ${ }^{38}$ Adam similarly greets Nicholas of Sandwich, prior of Christ Church Canterbury, with 'a spirit of salutary counsel and a spirit of unvanquished fortitude,' before chiding him for not yet confirming the peace settlement between the bishop of Lincoln and the chapter of Canterbury, 'where failing strength [uis] has not effectively given birth to what was salubriously conceived. ${ }^{39}$ His expressed desire that the prior might have divinely-provided counsel and fortitude is clearly meant to supply something deemed lacking. Adam's prayers for counsel and fortitude are not reserved for clerics: he also writes 'greetings and a spirit of salutary counsel with a spirit of unvanquished fortitude' to Simon of Montfort in 1251, in a letter which reprimands the earl for depriving a church of its vicar by bringing the cleric with him overseas. 'I do not know,' Adam

34 Letter 44 to Robert Grosseteste (undated), vol. 1, pp. 122-23: 'Preueniat, oro, uos in rebus spiritualibus spiritus consilii; subsequatur quoque spiritus fortitudinis.'

35 Letter 13, vol. 1, pp. 32-33: ‘(...) Nec sicut post frequentem sperandum est experientiam, benedicta sit gloria Domini de loco suo, in causis salutaribus propter semetipsum uobis sit defuturus spiritus consilii et fortitudinis “cum patientia et consolatione Scripturarum” [Rom. 15:4].'

36 Letter 145 to Peter of Savoy (undated), vol. 2, pp. 360 - 61: 'Hec est certe sapientie celestis dispensatio, ut nonunquam presidium auferat desperabili causarum difficultati quibus magnifice disponit diuinum prestare patrocinium (...).'

37 See, for example, letter 36 to Grosseteste, vol. 1, pp. 144-45.

38 Letter 58 to anonymous clerk, vol. 1, pp. 154-57.

39 Letter 90 to Nicholas of Sandwich (undated), vol. 1, pp. 226-29: '(...) Ubi uis defecta conaminis, que salubriter concepit, nequaquam edidit efficaciter.' 
goes on to write in the same letter, 'what obscured the clarity and prudence of your pious mind to cause such an error. (...) May a heavenly illumination enlighten you to consideration of the true will of God, that you be not seduced, which God forbid, by the deceits of the present age (...). ${ }^{40}$ Adam's use of this phrasing together with exhortations and reprimand may bear some relation to a similar formulation used in the dictamina in cases where a greeting of salvation ('salutem') cannot appropriately be given to the recipient, such as in the case of pagans, Jews, excommunicants, or those not leading pure lives. In such cases, 'in place of the salutation, it is said rather that they should have a spirit of sounder counsel [spiritum consilii sanioris]. ${ }^{, 41}$ Such a formulation at the opening of a letter was therefore a clear and efficient way of signalling one's belief that the recipient had strayed from the right path and can be found in such diverse documents as papal letter collections and Henry III's patent rolls. ${ }^{42}$ While Adam never employs this stronger formulation, his own references to the spirit of counsel at times carry a hint of the same reprimand.

Adam's repetition of the pairing of the spirits of counsel and fortitude has strong parallels to his understanding of the mixed life undertaken by those in ecclesiastical office. As he reminds several of his ecclesiastical correspondents, the 'mixed life' referred to by Augustine, which mingles the active and the contemplative life, is particularly appropriate to those who have been called to higher positions within the government of the Church. ${ }^{43}$ Such pastors need to engage in both activities, 'ascending at times to contemplate truth in God, and at other times descending to engage in active business out of charity for your neighbour. ${ }^{44}$ Just as counsel enables the action of fortitude, contemplation of divine truth through prayer and meditation enables one to undertake the activity of charitable works. As Adam writes to the Archdeacon of Lincoln, 'How will you fulfil the pastoral ministry by preaching the Gospel (...) unless you perceive through contemplative respite the works which you do with active

40 Letter 134 to Simon of Montfort (October 1251), vol. 2, pp. 326-27: 'Quid etenim claram pie mentis circumspectionem obtenebrauerit ignoro in re tam euidentis erroris (...). Reuelet uobis oculos celestis illuminatio ad considerandam diuine uoluntatis ueritatem, ne presentis seculi fallaciis seducti, quod absit (...).'

41 Guido Faba, Summa dictaminis, Il Propugnatore 3:13-14 (Bologna: R. Commissione pe' Testi di Lingua, 1890), lxii, p. 327.

42 On epistolary salutations, see Frank Anthony Carl Mantello and A.G. Rigg, Medieval Latin: An Introduction and Bibliographical Guide (Washington, D.C.: Catholic University of America Press, 1996), pp. 184-85. See for example, Innocent III's letter to King John (1212), Innocentii III Regestorum, letter 234 (PL 216:772D), and Calendar of Patent Rolls, Henry III: Volume 1, 1216-1225, ed. H.C. Maxwell Lyte (London: HMSO, 1901).

43 Letters 76 to Willliam Lupus, Archdeacon of Lincoln, pp. 192-95, and 245 to Sewal, archbishop of York, pp. 580-81; Augustine, De civitate Dei, ed. Bernhard Dombart and Alfons Kalb (Stuttgart: G. Teubneri, 1981), xix.2, vol. 2, p. 351.

44 Letter 78, to Giles Rufus, archdeacon of Northampton, vol. 1, pp. 202-3: ‘(...) Nunc per actionem otiosam ascendere ad contemplandam ueritatem in Deo, nunc per negotiosam actionem descendere ad impendendam caritatem proximo (...).' 
solicitude amid the darkness of men?' 45 The consideration of divine things brings insight, leading to right action. Adam tells Sewal, archbishop of York, that when he appoints ministers, he must do so with foresight born of heavenly consideration. ${ }^{46}$ Consideration of the truth should similarly preserve Simon of Montfort from being seduced by worldly deceits..$^{47}$ By intentionally devoting themselves to contemplation, pastors attain perception of the truth and inspiration toward charitable ministry; by seeking divine counsel, they are similarly equipped to complete arduous tasks with fortitude.

Adam's exhortations to seek divine counsel in a range of circumstances are particularly noticeable in his correspondence with Grosseteste, who has been provided with the steadfastness he requires for all his work through his trust in divine illumination..$^{48}$ In one letter, Adam writes that Grosseteste has already acted by the inspiration of divine illumination and that the only counsel he can think to offer is that he should continue to refer all his work to God, relying on him to supply his words, just as the Apostles did, 'for it shall be given you in that hour what to speak [Matt. 10:19]. ${ }^{49}$ More specifically, Adam emphasizes that divine aid is of great benefit to the bishop in selecting suitable candidates for presentation to ecclesiastical offices. He writes to Grosseteste that such candidates are found to be suitable 'as shown by the Holy Spirit' through Grosseteste's 'very searching investigation [per exactissimam uestre requisitionis industriam];' indeed, the worthy bishop is one who allies 'his tireless attention to the candidates for presentation to the cure of souls with the holy shrewdness of heavenly counsels [sancta celestium consiliorum calliditate]. ${ }^{50}$ The need for divine counsel also crops up in more particular circumstances where additional discernment is required. On one occasion, Adam writes to Grosseteste about a 'cheerful feast' which has taken place in London in which 'priests of God and ministers of the altar were divinely encouraged to participate,' but thereafter were censured for their lack of restraint. While disclaiming any knowledge of the circumstances of the case beyond common gossip, Adam underlines the need for careful and divinely-guided reflection, utilizing a fourfold consideration: 'What is proper to do concerning this, what is permissible, what is seemly, what is expedient, I pray that a genuine message from God may tell us, illumining a pure heart in a pious breast, piercing the darkness of contagion - "the clarity of eternal light, a mirror without

45 Letter 76 to William Lupus, vol. 1, pp. 194-95: 'Qualiter namque per predicationem euangelii ministerium pastionis adimplebitis (...) nisi per contemplatiuam uacationem in lumine conspiciatis quod per actiuam sollicitudinem in tenebris hominum faciatis?'

46 Letter 245.6a, vol. 2, pp. $580-81$.

47 Letter 134, vol. 2, pp. 326-27 (see above, n. 40).

48 Letter 52 to Grosseteste (3 June 1250), vol. 1, pp. 144- 45.

49 Letter 52 to Grosseteste (3 June 1250), vol. 1, pp. 144-45. See also letter 245.39a, vol. 2, pp. 632-33.

50 Letter 36 to Grosseteste (undated), vol. 1, pp. 106 -9. 
blemish" [Wisd. 7:26]. ${ }^{51}$ Having no certain opinion of how to judge or respond to these circumstances, Adam turns to prayer for divine illumination.

\section{Human Counsel}

Direct and individual divine illumination is not the only source from which Adam seeks insight: he also considers human counsel an important and accompanying means of navigating times of darkness and uncertainty - not in place of divine counsel but working alongside it. This aspect can be seen particularly clearly in Adam's writing because of the interpersonal nature of the epistolary genre, his letters often prompted by matters of concern or uncertainty in which it was only natural that counsel would be sought and given. Counsel was seen as one of the benefits of spiritual friendships and community, a means of assisting one another to fulfil the work of God and the Church. Adam makes several references in his letters to the importance of friendship and fellowship, not only to personal comfort and consolation but also to the spiritual battle. He even lists human fellowship (consortia humana) as one of the blessings called down from heaven, along with divine patronage and the protection of angels, by saints who persevered in their struggles against the tyrannies, violence, and falsities of the world..$^{52}$ To Grosseteste, who has written lamenting the absence of every one of his friends, Adam writes acknowledging that 'anyone who is excluded from the intercourse of friendship, which means mutual goodwill in adversity and the joy in one another's company, is recognized to be inexplicably tormenting himself. ${ }^{53}$ This absence of human aid, however, diverts attention to divine aid: Adam adds that no man can lack the consolation of friends when he is joined in fellowship with Christ. ${ }^{54}$ Likewise, human fellowship can prove an aid to spiritual insight: when Adam fears he is suffering 'incalculable harm to heavenly illuminations, that is to thoughts of eternity, truthful reasoning, or a tranquil will, on account of [being sucked into] the darkness of a vast abyss of worldly concerns,' he implores William of Nottingham, the provincial minister, to send him Brother John the papal nuncio, so that he might 'restore to me the stability and ordered progress I so desire.'55

51 Letter 37 to Grosseteste (undated), pp. 110 -11: 'Circa hec quid oporteat, quid liceat, quid deceat, quid expediat, insplendeat, oro, mundi cordis pio pectori emanatio illa Omnipotentis Dei sincera, decussa contagiorum caligine, "candorque lucis eterne, speculum sine macula”; see also Bernard of Clairvaux, De consideratione libri v, in Bernardi opera, ed. J. Leclercq and H.M. Rochais (Rome: Editiones Cistercienses, 1963), III.iv.15, p. 442.

52 Letter 48 to Grosseteste (August 1250), vol. 1, pp. 132-33.

53 Letter 28 to Grosseteste (May x June 1251), vol. 1, pp. 74-75.

54 Letter 28 to Grosseteste (May x June 1251), vol. 1, pp. 74-75.

55 Letter 171 to William of Nottingham (January x March 1250), pp. 408-11: ‘(...) Inestimabilia celestium illuminationum detrimenta, uidelicet eternitatis in mente, ueritatis in ratione, tranquillitatis in 
With counsel forming a fundamental part of his own spiritual role, Adam repeatedly emphasizes to his letters' recipients the importance of having wise and discerning spiritual counsellors. While the office of such a counsellor was rarely formal, it could form a very real part of a person's perceived role. ${ }^{56}$ Giving counsel was often considered one of the accepted responsibilities of holy people, especially those with a reputation for wisdom and discernment, such as Adam himself. ${ }^{57}$ Adam cites various characteristics which mark the excellent human counsellor, variously describing their counsels as faithful, discerning, God-fearing, truthful, wise, eloquent, prudent, and experienced. He also recommends counsellors who themselves possess the spirit of counsel: not being able to join Simon of Montfort in person, Adam reminds Simon that he has with him 'the lords of Lincoln [Robert Grosseteste] and Worcester [Walter Cantilupe], and Brother Gregory, who have, as I believe, the spirit of counsel, and who can, with God's favor, satisfy your requirements far better than my inadequate self, especially those that cannot be postponed. ${ }^{58} \mathrm{Good}$ counsellors are particularly important for men in positions of power and governance.

In advising bishops on the appointments necessary for them to make in order to accomplish their evangelical mission, Adam also includes amongst the required appointments of assistants, officers, and just judges the important role of faithful and discerning counsellors. ${ }^{59}$ Adam does not confine the need for counsel to strictly spiritual matters: for example, he advises Grosseteste to seek 'the counsel of the prudent' in dealing clemently with the case of an important nobleman. ${ }^{60}$ Good counsel can come from many quarters: Adam encourages Eleanor of Montfort to give counsel to her husband, not only 'to give him her constant help and care for everything related to the worship of God, righteous living, and right judgement,' but also to direct him in matters of governance. ${ }^{61}$ If, he writes to her, the earl has entered incautiously into treaties or contracts and made extravagant payments of money, 'it will be your part, through the very good efforts of your kind circumspection (...) to direct him by

uoluntate, propter immensas terrenarum caliginum uoragines (...) restituendo tam desiderabilem stabilium profectuum ordinem.'

56 Mendicant preachers and confessors were particularly expected to be approached for counsel on both spiritual and temporal matters: see, for example, Humbert of Romans, De eruditione praedicatorum in Opera de vita regulari, vol. 2, ed. J.J. Berthier (Rome: Typis A. Befani, 1888), XLIII, pp. $475-77$. 57 See, for example, Grosseteste, Epistolae, letter 99 to Walter Cantilupe (1242), p. 304.

58 Letter 142 to Simon of Montfort (c.1250), pp. 352- 53 (see note 75): 'Habetis presentiam dominorum Lyncolniensis, Wygorniensis, Fratris Gregorii, in quibus ut credo, est spiritus consilii, qui uobis diuinitate propitia satisfacere poterunt longe melius quam mea insufficientia super requisitis, presertim 〈hiis〉 que differri nequeunt.' Women could also be seen as providing counsel through the spirit of counsel: see, for example, Jacques of Vitry's early 13th-century Vita Marie de Oegnies, ed. R.B.C. Huygens, CCCM 252 (Turnhout: Brepols, 2012), II.6, pp. 127-28.

59 Letter 1, vol. 1, pp. 4-5; letter 8, vol. 1, pp. 22-23.

60 Letter 25 to Grosseteste (1249), vol. 1, pp. 60-61.

61 Letter 157 to Eleanor of Montfort (undated), vol. 2, pp. 378-79: ‘(...) Iugem iuuaminis impendere sedulitatem ad omnia in quibus aut Deus colitur, aut iuste uiuitur, aut recte iudicatur.' 
the tranquillity of your counsels to negotiate with more care in future. ${ }^{62}$ Her position as Simon's wife gives her a responsibility to provide him with discerning counsel.

Adam too feels an obligation to provide counsel. He offers his own counsel and assistance freely, particularly to his friends, even while humbly disclaiming its value. 'If there is in me any of the counsel or consolation that you mention in your letter,' he writes to Grosseteste, 'am I not available when required to be of use or in case of necessity? ${ }^{63}$ He seems to feel keenly the tension of responsibility required by him as a spiritual counsellor, especially to men he sees as instrumental to bringing about reform in the Church. When Boniface, archbishop of Canterbury, requests Adam's presence, Adam has doubts as to whether he should join the archbishop's active company or remain in silence and contemplative leisure. A point in favour of joining the archbishop seems to be the readiness with which he is now prepared to accept Adam's counsel, heeding him and bearing with his words of admonition. ${ }^{64}$ Adam sees the opportunity for his counsel to bear fruit.

Adam himself frequently calls upon Robert Grosseteste's counsel, either on his own or on others' behalf. In one letter, he beseeches him to receive Boniface and to give him 'efficacy of aid, eloquence of counsel, and guidance in his undertaking. ${ }^{95}$ In another, Adam requests that 'the circumspection of [Grosseteste's] more experienced counsel' should attempt to provide a remedy for an impending disturbance in the schools of Oxford, while also informing the bishop that Simon and Eleanor of Montfort are in much need of his salutary counsel, 'so that a written word may make up for what the spoken word cannot accomplish. ${ }^{66}$ As this last phrase implies, Adam has a strong preference for face-to-face counsel, but is frequently forced to rely on the written letter where distance and circumstance prevent meeting in person - it ought to be remembered that what his letters reveal is but the tip of the iceberg, a small indication of the abundance of counsel exchanged in person which has left no similar mark upon the historical record.

Divine and human counsel are not entirely separate sources of insight, but rather work together as one seeks counsel from those who have themselves been inspired by the Holy Spirit. Adam repeatedly returns requests for his counsel with exhortations for his letters' recipients to pray for divine counsel, even as he offers his own counsel alongside. Beginning his letter to Richard Gravesend about the prebend

62 Letter 159 to Eleanor of Montfort (1249x50), vol. 2, pp. 384-85: ‘(...) Vestrum erit per piissimam benigne circumspectionis industriam (...) ipsum ad cautius negotiandum de cetero per tranquillitatem consiliorum dirigere.'

63 Letter 13 to Grosseteste (undated), vol. 1, pp. 32-33: 'Et si quid in me poterit consilii aut consolationis, quarum meministis in littera, numquid non presto sum, cum hoc aut utilitas requirit aut compellit necessitas?'

64 Letter 180 to William of Nottingham (August 1253), vol. 2, pp. 436-37.

65 Letter 32 to Grosseteste (June 1250), vol. 1, pp. 92-93: 'Rogo igitur (...) cum ea que decet reuerentia suscipientes, et efficaciam auxilii, et consilii disertitudinem, et directionem propositi (...).'

66 Letter 21 to Grosseteste (1249x1250), vol. 1, pp. 48-51. 
of Thame, Adam writes, 'But since you ask for the counsel of my humble self in a great matter, allow, I beg you, the Angel of Great Counsel [magni consilii angelus] to answer you for the great increase of your salvation. ${ }^{97}$ The 'Angel' here refers not to a heavenly messenger but to Christ himself, a natural title to use when calling for divine counsel. ${ }^{68}$

Although Adam certainly offers Richard Gravesend plenty of his own counsel, urging him to assist the pope in appointing a suitable pastor to every vacant church, he also tells him that he cannot give a clear answer to Richard's 'intricate question' and speaks not as one offering counsel but one seeking truth. ${ }^{69}$ 'Truly,' he writes, 'I am in a thick darkness imposed by my own limitations. As far as I can see with trembling eyes, enabled by that light that shines in darkness, you would seem well advised, in the heavenly illuminations of the divine scriptures that illumine your humble mind, to strive to banish the infernal darkness that blinds you (...). ${ }^{90} \mathrm{He}$ concludes his letter with a prayer that by the inspiration of Almighty Wisdom, the spirit of counsel and fortitude will inspire Richard with the truth. ${ }^{71}$ Such juxtaposition with divine counsel can serve rhetorically to strengthen Adam's counsel - he tells his recipient to seek the counsel of God, confident that it will be seen to match what he himself has urged - but it also provides a kind of 'safety net', a surer foundation and a certain source of counsel when Adam's own counsel may be uncertain.

\section{Multilateral Deliberation}

In his discussion of both divine and human counsel, Adam remains fairly close to the conceptions and terminology of earlier thinkers, although his status as a spiritual counsellor and the nature of his letters lends the subject particular emphasis. His discussions of a third means of seeking truth, multilateral deliberation, however, take a more idiosyncratic approach. In a medieval context, deliberation (consiliari, also deliberare, tractare) was closely connected to consilium; it could cover both the process of turning a matter over within one's own mind, and that of engaging

67 Letter 75 to Richard Gravesend (May 1254), vol. 1, pp. 186-87.

68 This title originally appeared in the Vetus Latina translations of Isaiah 9, transmitted through the medieval period in patristic and liturgical texts: 'Puer natus est nobis, datus est nobis, cuius principium super humeros eius et vocabitur nomen eius magni consilii angelus (...).' Esaias, ed. R. Gryson, Vetus Latina, vol. 12 (Freiburg: Herder, 1989), Isaiah 9:6 (variant E1), pp. 288-93.

69 Letter 75, pp. 190 - 91 (see above, note 3).

70 Letter 75 to Richard Gravesend (May 1254), pp. 188-89: 'Verum sicut michi inter densissimas defectuum meorum caligines, ex luce que in tenebris lucet michi sublucere tremulis cum oculis aspicio, consultum esse uidetur ut iuxta celicas illuminationes celestium scripturarum humilem mentis uestre mansuetudinem luculentius illustrantes, densissimas infernalium excecationum tenebras (...).'

71 Letter 75 to Richard Gravesend (May 1254), pp. 190 - 91. 
in multilateral discussions over the matter with others. ${ }^{72}$ In considering this latter process, Adam focuses on the interpersonal nature of discussion and debate. While letters obviously play an important role in delivering and receiving counsel, Adam sets particular store by the potential of in-person deliberation, framing the perpetual search for truth and the correct course of action within a context of lively discussion and inquiry, with a potentially positive role even for disagreement.

As seen above, Adam seems to take great solace and consolation from his conversations with others. Encountering him as we do only through his letters, we often find him chafing against the constraints of pen and parchment, longing for a more active, multilateral discussion. He repeatedly sets his discussions of counsel within the wider value he places on friendship and on face-to-face 'living conversation', for which he often admits letters are but a poor substitute: 'the pen must supply, as it is able, what the tongue cannot do. ${ }^{73} \mathrm{He}$ writes to Eudes Rigaud, the Franciscan archbishop of Rouen, of his anxiety at not being able to come and speak with the archbishop in person, 'to be granted the heavenly consolation of a much desired conversation [colloquium] and to gain from the sacred abundance of your breast a mind singly set upon eternity, reason made clear by truth, and with God's favor a will rendered tranquil, more effective, and more transparent. ${ }^{, 74}$ Speaking together brings benefits of clarity and insight not fully possible through the slow and distanced exchange of letters.

The value of the spoken voice is made particularly clear in a letter Adam writes to Simon of Montfort, likely around 1250 while Simon was lieutenant in Gascony. ${ }^{75} \mathrm{Al}$ luding warily to the 'very great matter' which Simon has referred to him, Adam enters into an explicit consideration of discussion and debate as a means of arriving at the correct course of action. He begins by contrasting the dead letter (mortua littera), which presents but a single meaning, with the living voice (vox viva), which communicates its ideas in many forms (plures forme). The more complex nature of speech allows it to grapple more effectively with doubtful matters, for in the face of uncertainties, 'mute writing cannot at all answer anxious questions in the way that can be done by the multiplicity of living speech. ${ }^{76}$ He continues:

72 On consilium as deliberative rhetoric, see Shawn D. Ramsey, 'Consilium: A System to Address Deliberative Uncertainty in the Rhetoric of the Middle Ages,' Advances in the History of Rhetoric 15:2 (2012), pp. 204-21.

73 Letter 39 to Grosseteste (January 1250), vol. 1, pp. 112-13.

74 Letter 6 to Eudes Rigaud [= Odo Rigaldi] (1248 or later), vol. 1, pp. 16-17: ‘(...) Ut per optatum celice consolationis colloquium de sancta pii pectoris affluentia menti simplex eternitas, rationi clara ueritas, uoluntati placida tranquillitas, et efficacius et manifestius et salubrius diuinitate propitia concederetur.'

75 On dating of letter 142 (formerly 144), see Roger Haas, 'Adam Marsh (De Marisco), a ThirteenthCentury English Franciscan,' (PhD dissertation, Rutgers University, 1989), p. 380, n. 67.

76 Letter 142, vol. 2, pp. 350 -51: '(...) Et secundum sensum sapientis mortua littera unicum sensum preferat, uox autem uiua plures formas demonstrat, et nullatenus muta scriptura sic respondere ualet 
I know very well that courses of action, above all those related to great matters, are in no way so eloquently or so beneficially communicated through written words as are those that are openly transacted thanks to the illumination of the divine mercy through the diligence of deliberations and the many-sided nature of discussions [per diligentiam tractuum et multiformitatem discussionum] when men sincerely seek the honor of God and work for eternal life.

Is not this the reason why the blessed Apostles, each of whom received an immeasurable outpouring of the Holy Spirit, and the totality of ecclesiastical persons in their discernment, and the princes of the world with their shining wisdom, and the assemblies of lay people, have not ceased from the beginning of time to search [inuestigare] for what is right and to decide on courses of action through the living inquiries of conversing with one another [per colloquiorum uiuaces disquisitiones] ${ }^{77}$

Again, Adam highlights the 'many-sided' nature of such discussions, the need to gather together in person in order to investigate a matter and determine what is right. Grosseteste makes a similar point in a letter to Walter Cantilupe, answering his request for counsel as to whether he should accompany the king overseas. Grosseteste, relying on more philosophical terms than Adam, refrains from giving an immediate answer, claiming that his lack of experience in such matters prevents him from prudently anticipating the contingencies on both sides of the matter and thereby determining what decision ultimately will be best for the salvation of souls. He longs for Walter's presence, which would allow him to 'discuss this subject with [him] as carefully as possible, for many points are often revealed in mutual discourse [in mutuam collationem] that are completely overlooked in individual inquiries. ${ }^{, 78}$ Since he cannot meet with Walter, Grosseteste defers his answer until he has met with the wise and prudent Adam Marsh and discussed the matter ('habere collationem') with him; only after such deliberation will he inform Walter of what seems, to him, to be the best course of action. ${ }^{79}$ Grosseteste's description of mutua collatio and Adam's of multiformitas disussionum argue that the multilateral deliberation is more than the sum of its parts: they wish to discuss matters face-to-face, not just to benefit from others' counsel, but so that important considerations might come

sollicitis interrogationibus sicut potest sermonis multiplicitas.' See also II Corinthians 3:6: 'Littera enim occidit, Spiritus autem vivificat' ['For the letter kills, but the Spirit gives life.']

77 Letter 142, vol. 2, pp. 350 - 53: 'Et scio certissime quod nullo modo innotescunt aut tam prudenter aut tam salubriter ea quae sunt agenda, maxime circa res grandes, per caracteres scripture, que copiose et utiliter per diligentiam tractatuum et multiformitatem discussionum ex illuminationibus patefiunt diuine clementie, cum honor Dei sincere queritur et propter uitam eternam laboratur. Nonne propterea et beati apostoli, quorum unusquisque inestimabilem Spiritus Sancti affluentiam suscepit, et tota ecclesiasticarum personarum discretio et mundi principes, qui tanta splenduerunt sapientia, et populorum secularium contiones, a temporum exordiis per colloquiorum uiuaces disquisitiones ea que recta sunt inuestigare non desistunt et ea que exsequenda sunt disponunt?'

78 Grosseteste, Epistolae, letter 99 to Walter Cantilupe (1242), p. 304; translated in Letters of Robert Grosseteste, p. 322: '(...) Super his vobiscum diligentissime tractaremus; cum per mutuam collationem multa saepe pateant quae per se divisim disquirentes omnino latent.'

79 Grosseteste, Epistolae, letter 99 to Walter Cantilupe (1242), p. 304. 
to light through the multiformity of their deliberative interchange which might not occur to any one of them on their own.

Adam makes clear in his letter to Simon that important decisions should not be matters for individual insight alone - even for individuals who have received the outpouring of the Holy Spirit - or for the one-sided counsel of a letter. Even the Apostles, direct recipients of the outpouring of the Spirit at Pentecost, did not possess sufficient knowledge and discernment within themselves to make great decisions without meeting together in councils. ${ }^{80}$ Rather, such matters may be best hammered out in many-sided communal discussion and debate, particularly in 'great matters' in which there may be uncertainty and grounds for fear. These discussions should be undertaken with diligence and sincerity, guided by God-fearing intention. Of course, Adam here in no way abandons divine illumination in favor of human deliberation, but rather considers how such illumination might work through the discussions of those sincerely seeking God's will. It is by the grace of such divine illumination that these discussions can be brought to their proper end. While 'mute writing' is all that is now accessible to the historian, Adam's letters therefore point to a much richer foundation of deliberative and interpersonal counsel lying just beneath.

Involved as he was in difficult and contentious matters within the Church, the schools, and the royal court and parliaments, Adam cannot be accused of a naïve view of human deliberations. He is well aware of the disagreements that arise even amongst godly men and often exerts himself in the role of peacemaker. Even in the midst of his efforts for peace, however, there are indications that such disagreements may not always be harmful, and may in fact even further the truth. He discusses this possibility in a letter, also written around 1250, to Master John of Stokes, a member of Grosseteste's household, who had written to him of his difficulties in winning the hearts of Simon of Valence and Robert Marsh, both men well known to Adam (the latter is believed to be his brother). Adam responds to John, writing:

I am driven with all my poor strength by an urge to restore peace among churchmen, and also by the compulsion of a special friendship with each one of you. But the creator of souls and lover of souls commands heaven's rectors by the force of eternal law to display the prudence of a serpent and the simplicity of a dove [Matt. 10:16] for the salvation of souls; though He sometimes encourages disagreements without animosity [dissensiones sine odio], and is known to allow contests of sweet disputes [suavium litigiorum certamina], not to engender conflict but to establish concord; but discerning piety is ever active for the protection of beloved truth in such a way that true charity suffers no harm. ${ }^{81}$

80 For example, Acts 15:5-22.

81 Letter 118 to John of Stokes (c.1250), vol. 2, pp. 306-7: ‘(...) Totis exilitatis mee uiribus, preter saluificam emulationem pacis reficiende in uiris ecclesiasticis, me compellit apud unumquemque uestrum singularis amicitie necessitudo. Ceterum prudentie serpentine columbina simplicitas, qua spirituali legum eternarum cogentia rectores celicos pollere precipit saluandis animabus Auctor animarum, "qui amat animas", licet nonnumquam foueat dissensiones sine odio, et interdum dispensata suauium litigiorum certamina exercere cognoscatur, non controuersiis instaurandis sed con- 
The word he uses for 'contests', certamina, has forceful connotations, including physical battle, but it can also be used for exercises of training and testing. The book of Wisdom, for example, from which Adam frequently quotes, refers to the wisdom that is found in the 'contest of her [i.e. Wisdom's] speech [in certamine loquellae illius]. ${ }^{82}$ Litigium and its cognates, on the other hand, only appear in the Vulgate in reference to quarrels, dissensions, and legal disputes, and would rarely be combined with such a positive term as suavis. The adjective not only recasts litigium in a more positive light, but it also emphasizes the role of persuasion, as suavis shares its root with suadere, 'to advocate, to persuade. ${ }^{83}$ Adam's intentionally provocative word choice serves to emphasize his point as he describes a method of inquiry and peace-making that goes not around conflict but through it, articulating his confidence that truth and agreement may be preserved and perhaps even formed through disagreement.

The investigation and preservation of the truth through debate and disagreement had for some time been of concern to the schools. The explicit goal of the scholastic disputation was to inquire into a question, to mitigate doubt, and to pursue the truth regarding a matter of uncertainty, presenting opposing arguments and refutations before a definitive solution was arrived at by the master. ${ }^{84}$ In this context, opposition and dispute were framed as an aid, not a detriment, to investigating the truth. Masters and teachers of this mode of discussion were, however, well aware of its potential to stir up intemperate rancour and discord. Peter the Chanter's (d. 1197) discussion of the disputation, for example, stressed the modus disputandi necessary in order to dispute without engendering quarrels or contentions. He cautions against haste in speech and turns in contrast to the stability of counsel, noting that the saints of the early church 'resolved nothing and responded to nothing unless deliberation and counsel had already been held. ${ }^{85}$ Similar concerns about the uncharitable dangers of disputation can be found in the writings of Adam's contemporaries. ${ }^{86}$ Adam

cordiis; semper tamen satagat discreta pietas ut sic ueritas cara defendatur, ne offendatur uera caritas.'

82 Wisdom 8:18.

83 See for example Huguccio of Pisa's entry on sueo. Derivationes, ed. Enzo Cecchini and Guido Arbizzoni (Florence: SISMEL, 2004), §S210.2, p. 1121: 'Item a suavis suadeo -es -si -sum, hortari, consulere, monere, quod autem dicitur suadere quasi suavia dare vel dicere (...).'

84 On medieval practices of disputation, see Alex J. Novikoff, The Medieval Culture of Disputation: Pedagogy, Practice, and Performance (Philadelphia: University of Pennsylvania Press, 2013); Olga Weijers, In Search of the Truth: A History of Disputation Techniques from Antiquity to Early Modern Times (Turnhout: Brepols, 2013); Olga Weijers, A Scholar's Paradise: Teaching and Debating in Medieval Paris (Turnhout: Brepols, 2015).

85 Peter the Chanter, Verbum abbreviatum, bk. 5 (PL 205:35D): 'Item, exemplo sanctorum primitivae Ecclesiae, necnon et justorum eos praecedentium, etiam et aliorum seniorum praedictos sequentium, qui nihil solvebant, ad nulla respondebant, nisi deliberatione et consilio praehabito et praecedente.' 86 For example, Vincent of Beauvais' De eruditione filiorum nobilium, ed. Arpad Steiner (Cambridge, MA: Medieval Academy of America, 1938), XXI, pp. 73-75; Humbert of Romans, De officiis ordinis, in Opera De Vita Regulari (Rome: Typis Abefani, 1888), XII.iv, pp. 260 -61. 
here agrees that these disagreements should be without animosity, but conceives of a particularly active divine role amongst these dissensions, not only allowing but encouraging them in order to establish concord out of conflict, arriving through dialectic at a clearer understanding of the truth.

\section{Conclusion}

These passages, taken together with Adam's other considerations of truth, counsel, and human fellowship, emphasize the interconnectedness of those seeking the will of God. Those among the faithful engaged, at least to some degree, in the active life rely on the prayers, exhortations, counsels, and even the disagreements of others to help them to navigate the shadows of temporal uncertainties. However, while these counsels and deliberations do assist in mitigating uncertainty, Adam is very clear that the counsels of men ultimately rest in the hands of Almighty God. It is his consilium, his ultimate plan, which shall prevail. As Adam writes to Simon of Montfort, 'When confidence in worldly assistance is gone, the triumphant courage of the warriors becomes entirely dependent upon the invincible strength and protection of heaven, which in all ages cries aloud of itself with the words, Counsel and equity are mine; prudence is mine; strength is mine. By me kings reign (...) [Prov. 8:14-15]. ${ }^{, 87}$ It is for this reason that 'although much experience gives one slender hope that the needful circumspect counsels will prevail,' Adam tells the recipients of his letters to on no account lose faith but to direct their actions 'with the uncertainty of their outcome to a sure end which is the will of God. ${ }^{88}$

87 Letter 138 (1250x51), vol. 2, pp. 334-35.

88 Letter 136 to Simon of Montfort (after June 1252), vol. 2, pp. 330 - 31: 'Etsi multiplex experientia tenuem prestet fiduciam ad habenda super negotiis de quibus scripsistis circumspecta secundum quod res requirunt consilia, diuinitate tamen propitia, in cuius manu corda sunt regum, diffidendum nullatenus est (...) amiguos actionum nostrarum exitus ad certum finem diuine voluntatis dirigamus.' 
